\title{
28. STROMATOLITES WITH COCCOID AND FILAMENTOUS BLUE-GREEN ALGAE OF MESSINIAN AGE FROM SITE 374-IONIAN ABYSSAL PLAIN ${ }^{1}$
}

\author{
Stanley M. Awramik, Department of Geological Sciences, University of California, Santa Barbara, California
}

\begin{abstract}
Microfossils interpreted as coccoid and filamentous blue-green algae are found within disrupted stromatolitic laminae of Messinian age in Core 17 from Site 374, central Ionian Abyssal Plain, Mediterranean Sea $\left(35^{\circ} 50.87^{\prime} \mathrm{N} ; 18^{\circ} 11.78^{\prime} \mathrm{E}\right.$, depth $\left.4078 \mathrm{~m}\right)$. The coccoids are morphologically similar to members of the living Aphanocapsa in size and habit while the filaments, though rarer than the coccoids, morphologically resemble empty sheaths of Lyngbya and a smaller as yet unreferable form.

These cyanophyte-bearing stromatolitic sediments suggest shallow water accumulation near of above mean sea level during Messinian time.
\end{abstract}

\section{INTRODUCTION}

One of the many key arguments supporting the hypothesis that the Mediterranean was a shallow water evaporite basin during the late Miocene is the presence of laminated dolomitic mudstones interpreted as stromatolites (Hsü, 1972). Our present understanding of the biological and sedimentological dynamics in algal mat growth and stromatolite formation indicates that blue-green algae are (Golubic, 1973, 1976) and presumably always have been responsible for the construction of stromatolites (Awramik et al., 1976). Stromatolites ${ }^{2}$ are organosedimentary structures produced by the sediment trapping, binding, and precipitation activity of blue-green algae. Wavy laminated carbonates of presumed stromatolitic nature but without preserved cyanophytes commonly are called "cryptalgalaminites" (see Aitken, 1967). Preservd cyanophtic remains within ancient stromatolitic sediments are very rare, only a few localities have yet been discovered (Awramik et al., 1976). Similarly, preserved blue-green algal remains are uncommon to rare below the actively growing portion of Recent algal mats. Therefore it may be fortuitous for us to find the preserved algal remains and therefore the term cryptalgal is appropriate.

Fortunately in some of the core samples from DSDP Leg 42A Mediterranean cruise, cyanophytic microfossils were found within stromatolitic laminae. Park (in Schreiber, 1973, p. 101, 108, 109) found empty sheaths and fused trichomes reminiscent of Lyngbya and

\footnotetext{
${ }^{1}$ Contribution 62 of the Biogeology Clean Laboratory.

2 The term stromatolite conveys many different meanings. I, for one, favor a biosedimentological process oriented definition. Others restrict the term to laminated domes and columns. Kalkowsky's (1908) original definition has been superceded by revised meanings as our knowledge of processes associated with stromatolite development increases.
}

Microcoleu ) in dolomitic interphases of evaporites from the Mediterranean DSDP Leg 13.

In sections examined from Leg $42 \mathrm{~A}$ cores, the cyanophytic microfossils were dominated by coccoid forms with filaments rare. Pigmented empty sheaths similar to Recent Lyngbya are present, but no Microcoleus were observed.

The presence of blue-green algal microfossils within stromatolitic laminae suggests a shallow water accumulation, and using Recent analogs such as the Persian Gulf, Shark Bay, the Bahamas, and Baja California, places the most probable environment of deposition near or above mean low tide.

\section{PROCEDURE}

Eleven core samples (374-17-1, 34-37 cm, 374-17-1, 75-78 cm, 374-17-1, 83-86 cm, 374-17-1, 92-95 cm, 374-17-1, 103-106 cm, 374-17-1, 108-111 cm, 374-18$1,146-150 \mathrm{~cm}, 374-20-1,27-29 \mathrm{~cm}, 374-22-1,18-23$ $\mathrm{cm}, 374-22-1,45-49 \mathrm{~cm}$, and 374-22-1, 70-73 cm) were examined (1) by binocular microscope on freshly broken, sawed, and $\mathrm{HCl}$ etched surfaces to observe the nature of the laminations and search for large filamentous cyanophytes; (2) in thin section scanned under $400 \times$ and $1000 \times$ looking for smaller blue-green algal microfossils. Based on preliminary thin section studies, samples 474-17-1, 75-78 cm, 374-17-1, 83-86 cm, and 374-18-1, 146 and $150 \mathrm{~cm}$ were macerated in $\mathrm{HCl}$ then HF for organic residue studies. Freshly broken chips of these three samples were then prepared and studied under SEM.

\section{RESULTS}

Thin sections studied by conventional white-light microscopy provided the only useful data in this preliminary report. Binocular microscopic studies of surfaces, SEM, and macerations yielded no useful data. 
Only two thin sections, one each from Samples 374$17,75-78 \mathrm{~cm}$ and $374-17-1,83-86 \mathrm{~cm}$ yielded a wellpreserved cyanophytic microbiota. Coccoid morphotypes (Plate 1) dominated in both thin sections, filamentous cyanophytes were rare. One well-preserved sheath similar to the Recent filamentous blue-green algal Lyngbya was found (Plate 1).

\section{The Coccoid Cyanophytes}

The blue-green algal nature of the coccoid forms is inferred by their close morphological similarity to extant coccoid blue-green algae, in particular Aphanocapsa (see Geitler, 1932), and occurrence in stromatolitic laminae. Some of the coccoid forms are squashed. The cells are double walled (Plate 1) and range in size from 5 to $15 \mu \mathrm{m}$ (Figure 1); a range common in coccoid blue-green algal.

From both thin sections 455 coccoids were measured. There were no differences in size ranges between the two thin sections. One well-defined population ranging from 5 to $9.6 \mathrm{~m}$ was found (Figure 1) while possibly another population may exist from 11.4 to $15 \mu \mathrm{m}$ (data are too few at present).

These fossil coccoid cyanophytes resemble the cells of Aphanocapsa (Figure 2; see Geitler, 1932, p. 148$161)$. Though I stress that caution must be exercised in the practice of comparing fossil morphotypes with extant textbook descriptions of blue-green algae, this comparison is compelling based on my observations: (a) cell-size is well within those of Aphanocapsa; (b) the cells are commonly found in nests of from 4 to 7 cells and are rarely found isolated reflecting a habit encountered in Aphanocapsa: few to many cells within a common envelope; (c) Aphanocapsa is present in the algal mats from Laguna Mormona, Baja California. Aphanocapsa, however, is a rare mat builder in today's algal mat environments.

\section{The Filamentous Cyanophytes}

Only 15 specimens of filamentous morphotypes of a probable blue-green algal affinity were encountered in the two thin sections. Diameter of the filaments ranged from 1.2 to $13.3 \mu \mathrm{m}$. Preservation (save for one specimen) was poor, therefore I do not know if sheath or trichomes were measured; most likely both. One specimen, yellow-brown in color, was found in Sample $374-17-1,83-86 \mathrm{~cm}$ that resembled an empty sheath of Lyngbya. The sheath is lamellated which is consistent with a comparison to Recent Lyngbya. Lyngbya in algal mats commonly preserved as empty brown sheaths below the actively growing mat surface (Horodyski et al., in press). However, until more data are available, I prefer to say "probable filamentous bluegreen algae present."

\section{DISCUSSION}

Laminated dolomitic mudstones with preserved cyanophytic remains from Site 374, Section 17 confirm the presence of stromatolites and support the subaerial to shallow water deposition environmental model for the Messinian of the Mediterranean. The dominant blue-green algal morphotype encountered resembles the modern coccoid cyanophyte Aphano- capsa. The role of Aphanocapsa in algal mats is relatively unknown, but found in some Baja California algal mats. The habit of these Aphanocapsa-like forms during Messinian time is uncertain, they may have been planktonic or benthic mat builders.

The most promising and potentially significant cyanophytic microfossils in this study are the filamentous forms resembling Lyngbya.

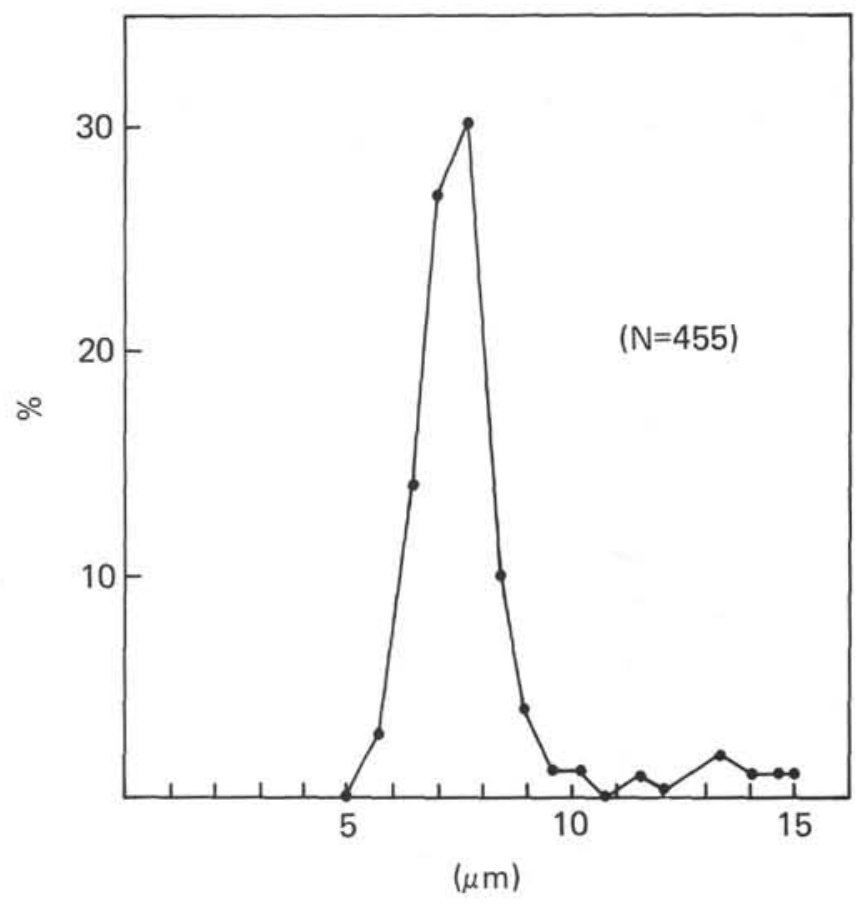

Figure 1. Frequency diagram for populations of unicellular algae in Messinian evaporites.

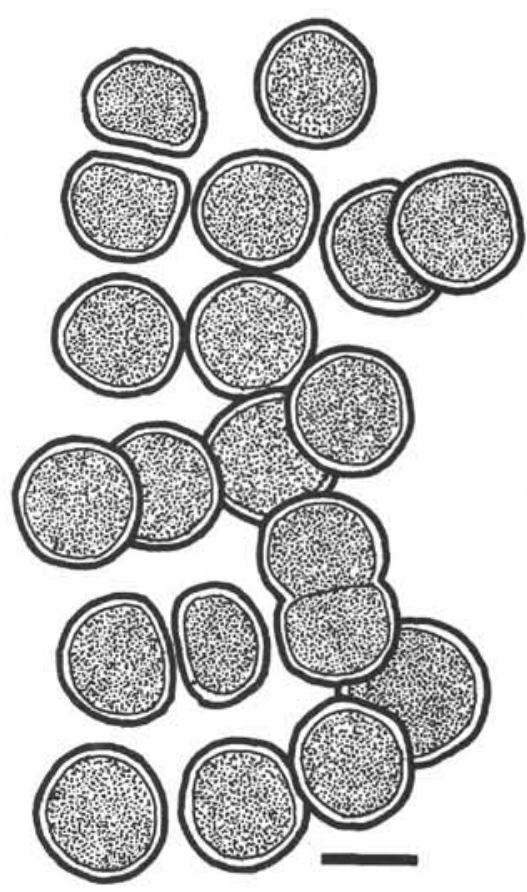

Figure 2. Aphanocapsa sesiacensis Fremy (from Geitler, 1932, p. 152; bar equals $10 \mu \mathrm{m})$. 


\section{ACKNOWLEDGMENTS}

I thank R. Garrison for additional Leg 42A samples and core data, D. Pierce for scanning electron microscope studies, and the discussions and comments on this preliminary report by C. Gebelein and R. Horodyski.

\section{REFERENCES}

Aitken, J. D., 1967. Classification and environmental significance of cryptalgal limestones and dolomites, with illustrations from the Cambrian and Ordovician of southwestern Alberta: J. Sediment. Petrol., v. 37, p. 1163-1178.

Awramik, S. M., in press. Paleobiology of stromatolites: Origins Life.

Awramik, S. M., Margulis, L., and Barghoorn, E. S., 1976. Evolutionary processes in the formation of stromatolites. In Walter, M. R., (Ed), Stromatolites: Amsterdam (Elsevier, p. 148-162.

Geitler, L., 1932. Cyanophyceae. In Rabenhorst's Kryptogamen-Flora, 14. Akademische Verlagsgesellschaft, Leipzig (Johnson Reprint Corporation, 1971), p. 1196.

Golubic, S., 1973. The relationship between blue-green algae and carbonate deposits. In Carr, N. G., and Whitton, B.
A. (Eds), The biology of blue-green algae: Oxford, (Blackwell), p. 434-472.

Golubic, S., 1976. Organisms that build stromatolites. In Walter, M. R., (Ed), Stromatolites: Amsterdam (Elsevier), p. 113-126.

Horodyski, R. J., Bloeser, B., and Vonder Haar, S., in press. Laminated algal mats from a coastal lagoon, Laguna Mormona, Baja, California, Mexico: Application to the interpretation of preserved Paleozoic cyanophyte mats: J. Sediment. Petrol.

Hsü, K. J., 1972. Origin of saline giants: a critical review after the discovery of the Mediterranean evaporite: Earth Sci. Rev., v. 8, p. 371-396.

Kalkowsky, E., 1908. Oolith and Stromatolith in norddeutschen Buntsandstein: Dtsch. Geol. Ges., v. 60, p. 68-125.

Schopf, J. W., 1975. Precambrian paleobiology: problems and perspectives: Ann. Rev. Earth Planet. Sci., v. 3, p. 213-249.

Schreiber, B. C., 1973. Survey of the physical features of Messinian chemical sediments. In Drooger, J. C., (Ed.), Messinian events in the Mediterranean: Koninkl. Nederlandse Akad. Wetensch., p. 101-110.

PLATE 1

Fossil blue-green algae

Figure $1 \quad$ Unicellular alga (374-17-1, 83-86 cm; coordinates $99.4 \times 114.5)$.

Figure 2 Unicells within stromatolitic laminae (374-17-1, 83-86 cm; coordinates $97.3 \times 105-7)$

Figure 3 Nest of unicells (374-17-1, 83-86 cm; coordinates $96.0 \times 13.9$ )

Figure 4 Empty sheath of Lyngbya like microfossil (374-17-1, 83-86 cm; coordinates $92.9 \times 14.2)$. Bar equals $10 \mu \mathrm{m}$.

(see p. 668) 
PLATE 1
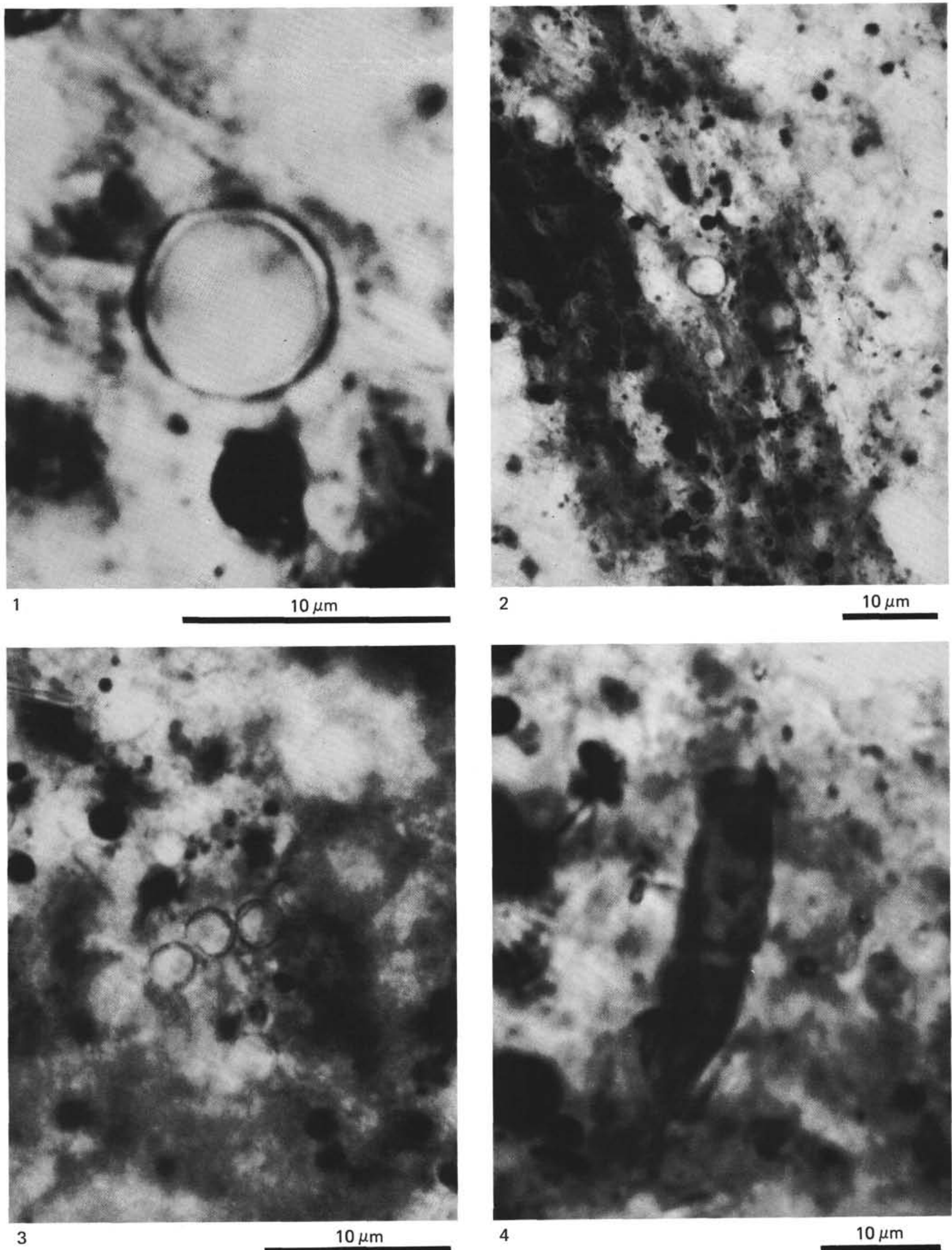